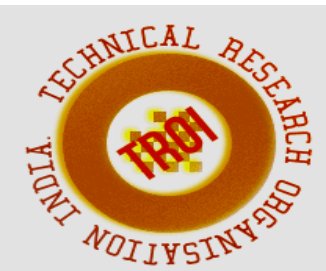

\title{
EXPERIMENTAL STUDY ON THE TREATMENT OF DAIRY WASTE WATER USING LOW COST NATURAL ADSORBENTS
}

\author{
Divya $\mathrm{K} \mathrm{S}^{1}$, Dr.Syed Ariff ${ }^{2}$ V Vaishnavi ${ }^{3}$, Sadiya Banu A S ${ }^{4}, \mathrm{G}_{\text {Swetha }}{ }^{5}$, Ravi Kiran $\mathrm{S}^{6}$ \\ ${ }^{1}$ Assistant Professor, ${ }^{2}$ Professor \& Principal, ${ }^{3,4,5,6}$ Students Department of Civil Engineering, \\ Dr.T.Thimmaiah Institute of Technology, KGF \\ Emailid:divya@drttit.edu.in ${ }^{1}$
}

\begin{abstract}
Dairy industry is the one of the pollution food industry and considering huge amount of water is used during production of milk and its products. The waste water contains dissolved sugars, proteins, and fat which is biodegradable and organic in nature. So that dairy waste water is considered as high concentration of organic matter and high BOD. It is estimated that dairy industries generate 2.5 to 3 litres of waste water per litre of milk processed. Such untreated waste water pollutes land and water bodies so that proper treatment of dairy waste water is necessary before disposal in the environment. The aim of present research work is to determine behaviour of various parameters of dairy waste water. An investigation of possible use of low cost natural adsorbents in their powdered form like rice husk, curry leaf, orange peel, neem leaf and rice husk in the treatment of dairy waste water. After conducting the experiments we found that the COD, BOD, Turbidity and $\mathrm{pH}$ of the dairy waste water is reduced.
\end{abstract}

KEYWORDS: Dairy waste water, Natural adsorbents, COD, BOD, Turbidity and pH

\section{INTRODUCTION}

The dairy industry involves processing of raw milk, into products like consumer milk, butter, cheese, yogurt etc. Dairy industry contains high amount of organic constituents. So, it is needed to provide required treatment before discharge into the environment. The treatment mostly classified as aerobic and anaerobic treatment. Due to rapid industrial growth world's economy improve with rid growth but also that make impact in terms of pollution on environment. Large concentration of pollutants in terms of quantity and quality of liquids, solids, and gaseous pollutants shows harmful effects on flora and fauna as well as on many areas on environment. Organic toxic waste (oil and grease $(\mathrm{O} \& \mathrm{G})$ ) causes ecology damages for aquatic organisms, plant, animal, and equally, mutagenic and carcinogenic for human being. They discharge from different sources to form a layer on water surface that decreases dissolved oxygen. O\&G layer reduces biological activity of treatment process where oil film formation around microbes in suspended matter and water. This lead to decrease dissolved oxygen levels in the water. There are various methods of oil and grease removal that one of the examples is by using adsorption method. This method commonly uses activated carbon that is one Of the effective adsorbents. Although effective, the cost for activated carbon is expensive thus a study was conducted by using natural resources as alternative adsorbents for oil and grease removal. This study objective is to determine the ability of three adsorbents, which are curry leaf and neem as an adsorbent in removing oil and grease from wastewater. It involved the characterization of adsorbent and the performance studies of the adsorbent. Many technologies are in practice to treat the dairy wastewater and in the present study; an attempt was made to investigate the application of low cost adsorbents from orange peel for the treatment by considering the wastewater from local dairy form. Tones of orange peels were discarded and send to garbage as useless materials and it is very significant and even essential to find applications and uses for these peels, as the management of wastes nowadays 
is becoming a very serious environmental issue. These waste peels are low cost, non-hazardous and environment friendly bio-materials which can be used as adsorbents in wastewater treatment. By addition of these adsorbents reduces the pollutants present in the dairy waste water and maintain the COD, BOD, Turbidity and $\mathrm{pH}$. For effective resultant add neem leaf, curry leaf, rice husk and orange peel in a mixed adsorbent form.

\section{LITERATURE REVIEW}

\section{A.k.Balaji, H.Amarnath, A.L.}

Balasubramaniyan (2018) [1] Removal of oil from dairy waste water by using natural adsorbent. There is several pollutants that can harm our environment. Oil is one of the examples of pollutant that can cause environmental problem when present in dairy Waste water. This study objective is to determine the ability of three adsorbents i.e., curry leaf, neem leaf, and banana pith to remove oil from dairy waste water.

Thuraiya Mahir Al Khusaibi, Joefel Jessica Dumaran, M. Geetha Devi, l. Nageshwara rao and

S. Feroz (2015) [2] Treatment of dairy waste water using orange and banana peel. An experimental investigation was carried out for the treatment of dairy waste water using low cost adsorbents. The peel of orange and banana were used as adsorbents in this study by carbonization and dehydration methods the optimum PH for both methods 6-8. The orange peel found to be more efficient effective peel where percentage of removal of pollutant is $50.1 \%$ and $14.3 \%$ where banana peel removed pollutants $44.1 \%$ and $8.2 \%$ for carbonization and dehydration. Uttarini Pathak (2011) [12] Investigated on Treatment of Wastewater from a Dairy Industry Using Rice Husk as Adsorbent: Effluent from milk processing unit contains soluble organics, suspended solids, and trace organics releasing gases, causing taste and odour, and imparting colour and turbidity produced as a result of high consumption of water from the manufacturing process, utilities and service section, chemicals, and residues of technological additives used in individual operations which makes it crucial matter to be treated for preserving the aesthetics of the environment. In this experimental study after determination of the initial parameters of the raw wastewater it was subjected to batch adsorption study using rice husk.

\section{OBJECTIVE}

Removing of organic matter by adsorption process and reduction of COD, BOD, Turbidity and maintain $\mathrm{pH}$ of waste water.

\section{METHODOLOGY}

Water is a valuable natural resource for the existence of all living organisms. Indian rivers are polluted due to the discharge of untreated sewage and industrial effluents. Management of the quality of this precious resource is, therefore, of special importance. Disposing different kinds of wastewater such as domestic, industrial and agricultural effluent into environment, especially to surface water, can cause heavy pollution of this body sources. With regard to increasing wastewater disposed standards to the environment, high considerations should be made when selecting proper treatment processes. Any of chemical, biological and physical treatment processes have its own advantages and disadvantages. It should be kept in mind that economical aspects are important, too. In addition, employing environment friendly methods for treatment is emphasized much more these days. In this study, dairy effluent is collected and analyzed for different parameters such as $\mathrm{pH}$, Turbidity, BOD and COD. After checking such parameters natural adsorbents are used to absorb the impurities.

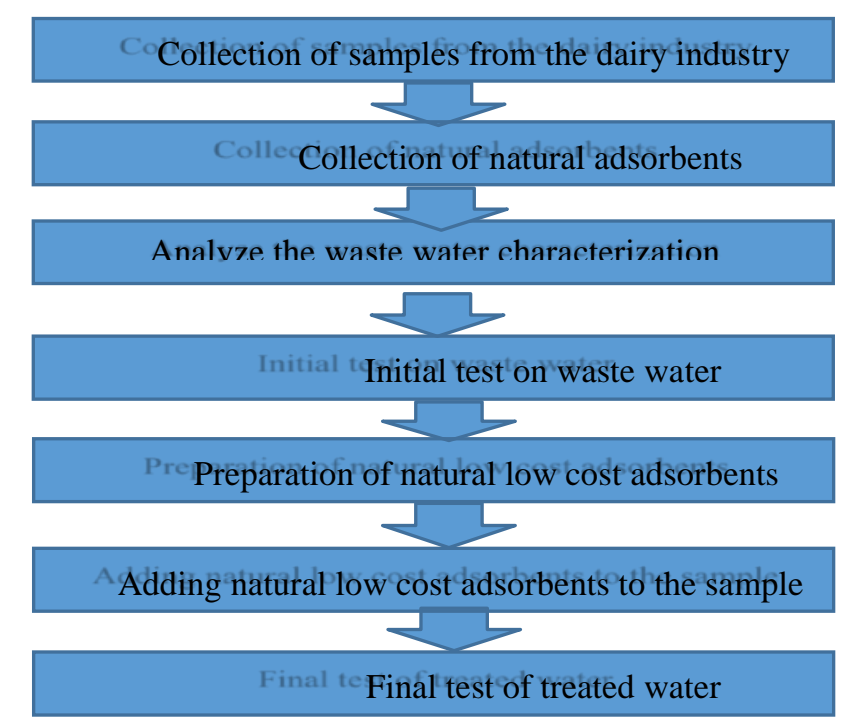

FLOW DIAGRAM 


\section{ADSORBENTS IN THE POWDERED}

\section{FORM}

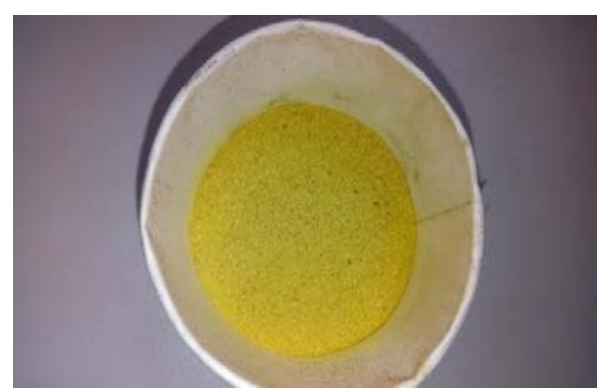

Figure: Orange peel in powdered form

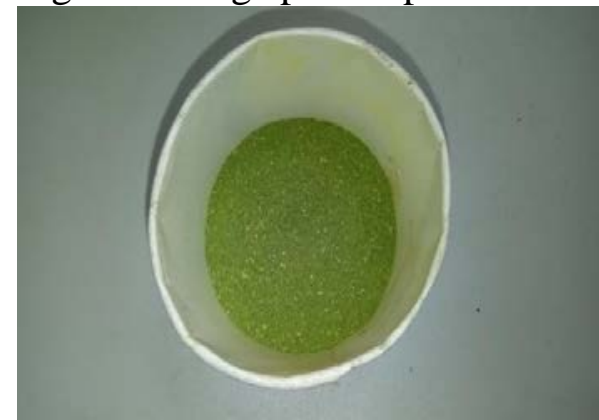

Figure: Neem leaf in powdered form

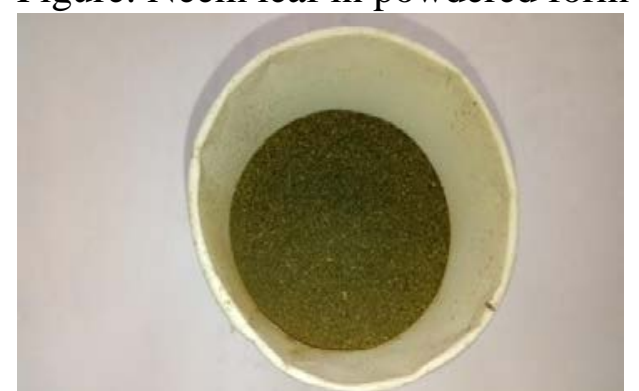

Figure: Curry leaf in powdered form

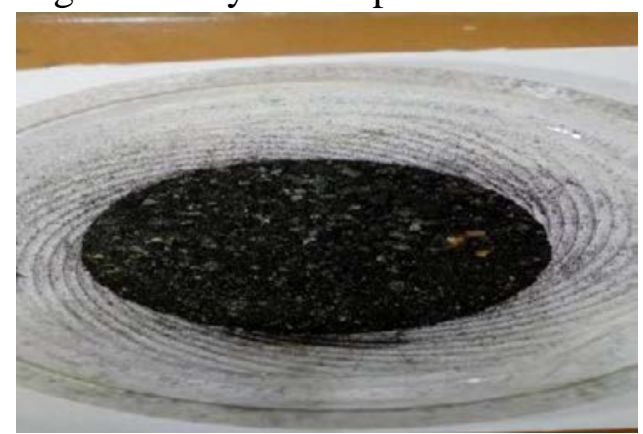

Figure: Rice husk ash

6. INITIAL TEST

\begin{tabular}{|c|c|c|}
\hline SL.NO & TESTS & $\begin{array}{c}\text { RESULT } \\
\mathrm{S} \\
\end{array}$ \\
\hline 1 & $\mathrm{pH}$ & 10 \\
\hline 2 & COD & $61.44 \mathrm{mg} / \mathrm{l}$ \\
\hline 3 & BOD & $90 \mathrm{mg} / \mathrm{l}$ \\
\hline 6 & Turbidity & 448 NTU \\
\hline
\end{tabular}

7. RESULTS AND DISCUSSION

\begin{tabular}{|c|c|c|c|c|c|}
\hline TESTS & $\begin{array}{c}\text { Orange } \\
\text { peel }\end{array}$ & $\begin{array}{c}\text { Neem } \\
\text { leaf }\end{array}$ & $\begin{array}{c}\text { Curry } \\
\text { leaf }\end{array}$ & $\begin{array}{c}\text { Rice } \\
\text { husk }\end{array}$ & $\begin{array}{c}\text { Mixed } \\
\text { Adsor } \\
\text {-bents }\end{array}$ \\
\hline pH & 5.9 & 5.8 & 6.9 & 6.8 & 5.8 \\
\hline COD & 0.64 & 164.48 & 215 & 39.68 & 131.84 \\
\hline BOD & 0 & 24 & 40 & 5 & 18 \\
\hline $\begin{array}{c}\text { TURBI } \\
\text {-DITY }\end{array}$ & 291 & 0 & 75 & 100 & 3 NTU \\
\hline
\end{tabular}

$\mathrm{pH}$

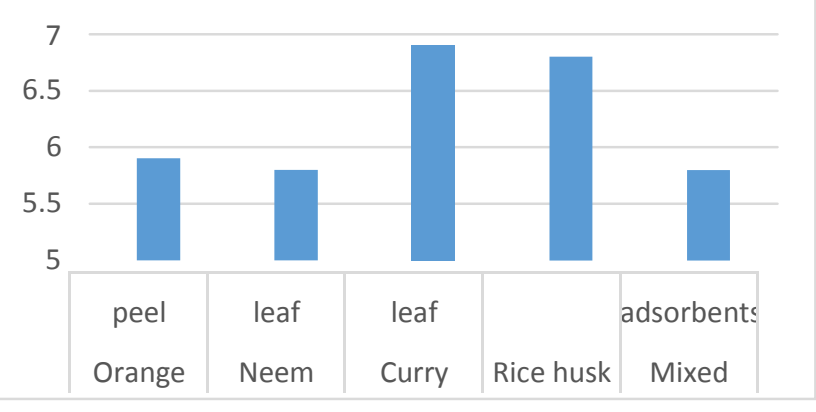

\section{COD}

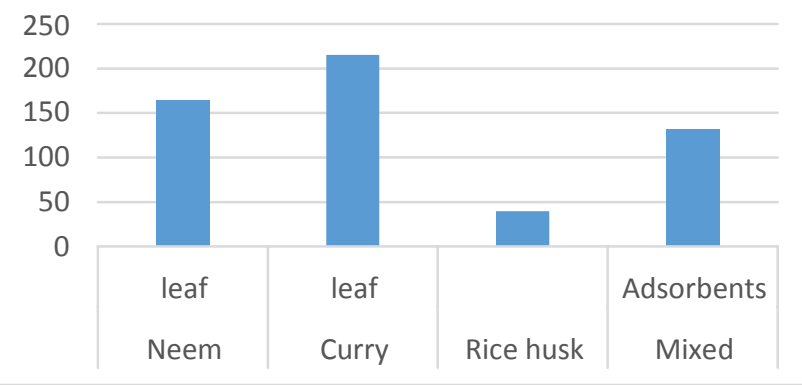

\section{BOD}

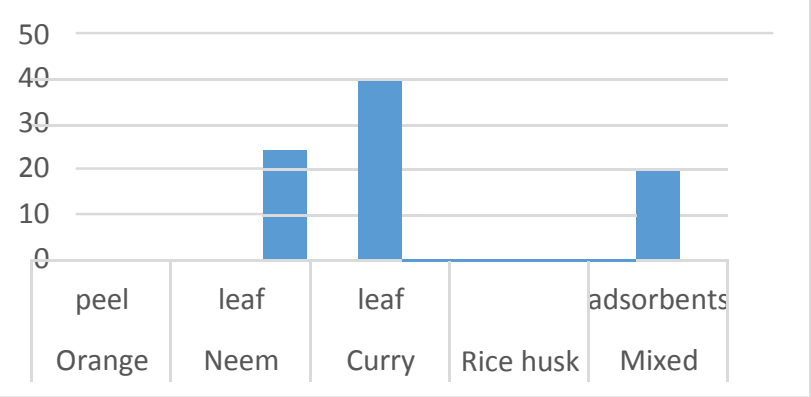




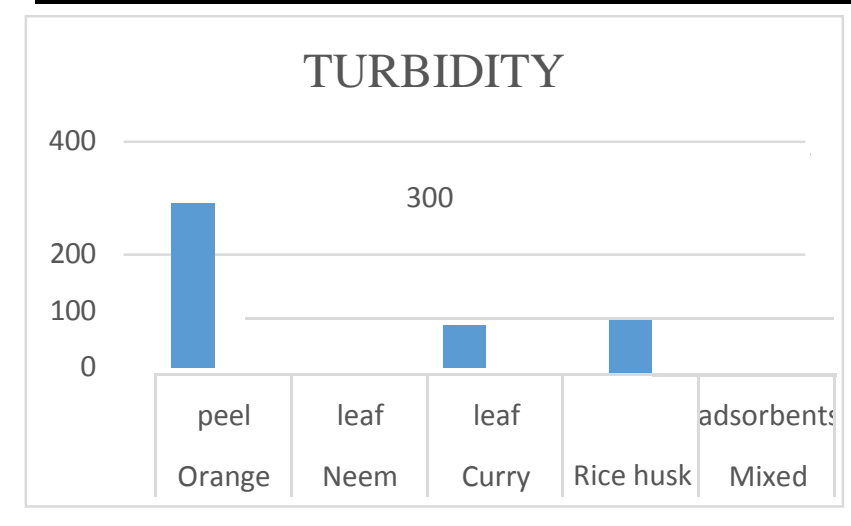

\section{CONCLUSION}

An experimental study is conducted on the treatment of dairy waste water using low cost natural adsorbents and during treatment we have found that before adding the adsorbents the values of COD, BOD, Turbidity, $\mathrm{pH}$ and total solids are very high indicating that it cannot be used for any domestic purposes. After the addition of adsorbents the values have reduced indicating that it can be used for domestic purposes such as cleaning, flushing. Gardening, washing etc. By conducting tests we have found that among all the four adsorbents orange peel shows best results in reducing COD, BOD whereas neem leaf has efficiently reduced turbidity and on using curry leaf, rice husk, crab shell $\mathrm{pH}$ is maintained along with the reduction of odour.

\section{REFERENCES}

[1] Sasirekha P. (2017) "Removal of fluoride using chemical and natural coagulant", International journal on recent and Innovative trend in technology.vol3, Issue 3, pp.36-41.

[2] APHA (1995) standards methods for the examination of water and waste water, American public Health Association, American water works Association and water pollution control Federation, 19th end, Washington, D.C

[3] B.S. Shilpa, Akanksha, Kavita, P. Girish, (2012),-Evaluation of Cactus and Hyacinth Bean Peels as Natural Coagulants, International Journal of Chemical and Environmental Engineering, Volume 3, June 2012. Chidanand P,

Manika H, (2015) Treatment of dairy wastewater by natural coagulants. International Research Journal of Engineering and Technology 2:1120-1125.
[4] Choy S, Prasad K, Wu T, Raghunandan $M$ et al. (2014) Utilization of plant-based natural coagulants as future alternatives towards sustainable water clarification. Journal of Environmental Sciences 26: 2178-2189.

[5] Ellis Chlorination and Disinfection of Water (1988) Journal, American Water Association 336(4):28-4 